DOI: https://doi.org/10.47405/mjssh.v6i6.824

\begin{tabular}{|c|c|}
\hline 4.581 & Malaysian Journal of Social Sciences and Humanities (MJSSH) \\
\hline $\begin{array}{l}\text { Malaysian Journal of } \\
\text { Social cciences and }\end{array}$ & Volume 6, Issue 6, September 2021 \\
\hline (MJ-SSH) & e-ISSN : 2504-8562 \\
\hline & $\begin{array}{l}\text { Journal home page: } \\
\text { www.msocialsciences.com }\end{array}$ \\
\hline
\end{tabular}

\title{
Tahap Pematuhan Standard 1 SKPMg2 dalam kalangan Guru Besar Terhadap Motivasi Guru di Negeri Johor
}

\author{
Syakirin bin Saulani ${ }^{1}$ \\ ${ }^{1}$ SK Pogoh, Segamat, Johor \\ Correspondance: Syakirin bin Saulani (syakirinsaulani@gmail.com)
}

\begin{abstract}
Abstrak
Standard 1 SKPMg2 berfokuskan kepada kepimpinan guru besar di sekolah. Dalam standard ini, 3 aspek utama berkaitan fungsi dan tugas guru besar di sekolah adalah ditekankan iaitu Guru Besar Sebagai Peneraju, Guru Besar Sebagai Pembimbing dan Guru Besar Sebagai Pendorong. Kajian ini bertujuan umtuk mengkaji pengaruh tahap pematuhan Standard 1 SKPMg2 dalam kalangan guru besar terhadap motivasi guru di sekolah. Kajian yang menggunakan reka bentuk korelasi ini melibatkan 120 orang peserta kajian yang dipilih melalui persampelan rawak mudah menggunakan instrumen borang soal selidik yang mengandungi tiga bahagian iaitu Bahagian A: Demografi, Bahagian B: Tahap Pematuhan Standard 1 SKPMg2 Dalam Kalangan Guru Besar dan Bahagian C: Tahap Motivasi Guru. Data dianalisis menggunakan Statistical Package for Social Science version 23. Hasil analisis hubungan antara tahap pematuhan Standard 1 SKPMg2 dalam kalangan guru besar dengan tahap motivasi guru melalui ujian korelasi menunjukkan nilai $\mathrm{r}$ adalah $0.985(\mathrm{p}=0.000<0.001)$. Dapatan analisis membuktikan hubungan yang sangat kuat antara tahap pematuhan Standard 1 SKPMg2 dalam kalangan guru besar dengan motivasi guru di sekolah. Dapatan daripada kajian ini diharapkan dapat memberikan manfaat kepada guru besar dalam membuat penambahbaikan terhadap tahap pematuhan Standard 1 SKPMg2 seterusnya dapat meningkatkan mutu kepimpinan dan motivasi guru di sekolah.
\end{abstract}

Kata kunci: standard 1, SKPMg2, motivasi

\section{Level Of Compliance with Standard 1 SKPMg2 Among Headmasters Towards Teacher's Motivation in Johor}

\begin{abstract}
Standard 1 SKPMg2 focuses on the leadership of headmaster in school. There are 3 main aspects related to the functions and duties of the headmaster in the school; namely the Headmaster as a Leader, the Headmaster as a Mentor and the Headmaster as a Motivator. This study aims to examine the influence of the level of compliance with Standard 1 SKPMg2 among headmaster towards the teacher motivation in school. Correlation design is used in this study which involved 120 samples selected through simple random sampling. The instrument used is a questionnaire that contains three parts, namely Part A: Demographics, Part B: Level of Compliance with Standard 1 SKPMg2 Among Headmaster and Part C: Level of Teacher's Motivation. Data were analyzed using Statistical Package for Social Science version 23. The results of the analysis of the relationship between the level of compliance with Standard 1 SKPMg2 among headmaster with the level of teacher motivation through correlation test showed that the value of $r$ was $0.985(p=0.000<0.001)$. The findings revealed that a very strong relationship between the level of compliance with Standard $1 \mathrm{SKPMg} 2$ among headmaster
\end{abstract}


with the level of teacher motivation in school. Due to that, this study is expected to provide benefits to headmasters in making improvement to the level of compliance with Standard 1 SKPMg2 which in turn can improve the quality of their leadership and motivation of teachers in schools.

Keywords: standard 1, SKPMg2, motivation

\section{Pengenalan}

Dalam konteks sekolah, kejayaan sesebuah institusi itu ditentukan oleh kewibawaan dan kecemerlangan yang dipamerkan oleh pemimpin sekolah. Sehubungan itu, guru besar merupakan pemimpin tertinggi yang berperanan penting untuk merancang dan menyusun atur strategi-strategi yang berkesan terhadap pelaksanaan aktiviti-aktiviti di sekolah. Hal ini bertepatan dengan pernyataan oleh Jemaah Nazir Malaysia (1993) yang menyatakan bahawa guru besar adalah individu yang bertanggungjawab ke atas setiap yang berlaku di sekolah dan persekitarannya.

Bagi tujuan itu, Kementerian Pendidikan Malaysia (KPM) telah memperkenalkan Standard Kualiti Pendidikan Malaysia Gelombang 2 atau lebih dikenali sebagai SKPMg2 yang bertujuan untuk meningkatkan kualiti pengoperasian sekolah di mana semua aspek penilaian SKPMg2 adalah berdasarkan perkara dan tanggungjawab sedia ada di sekolah. Hal ini adalah seiring dengan hasrat yang dinyatakan dalam Gelombang 1 Pelan Pembangunan Pendidikan Malaysia (PPPM) 2013-2025 iaitu untuk mewujudkan pembimbing pengetua/guru besar yang berdedikasi untuk sekolah Band 5, 6 \& 7 dan mengukuhkan kriteria pemilihan untuk pemimpin sekolah bagi meningkatkan kualiti kepimpinan sekolah (KPM, 2013).

SKPMg2 dibina dengan format baharu yang menggantikan SKPM dengan tujuan yang masih sama iaitu sebagai panduan kepada pentadbir dan warga sekolah dalam meningkatkan keberkesanan pengurusan dan proses penyampaian pendidikan. Instrumen-instrumen yang terkandung dalam SKPMg2 adalah berorientasikan tindakan, menitikberatkan kualiti dan berasaskan evidens. Penilaian menggunakan instrumen ini berlaku sepanjang tahun serta melibatkan warga sekolah secara menyeluruh. SKPMg2 mempunyai 5 standard yang mana Standard 1 adalah berfokus kepada kepimpimpinan guru besar sebagai peneraju, pembimbing dan pendorong kepada warga sekolah.

Justeru, dalam memastikan kejayaan dan keberkesanan setiap perancangan yang telah diatur, guru besar memerlukan sokongan dan kerjasama daripada orang-orang bawahannya untuk melaksana dan menjayakan setiap perancangan yang telah diatur. Dalam hal ini, guru-guru merupakan pelaksana kepada semua agenda tersebut. Oleh yang demikian, gaya kepimpinan guru besar adalah penting dalam membina hubungan baik dengan semua guru dan warga sekolah selaku koordinator, pengawal, perancang dan pelaksana (O'sullivan et al, 1990). Hal ini juga adalah seiring dengan pendapat Abdul Aziz (2003) dalam Laporan Mesyuarat Gerakan Pengetua Cemerlang pada tahun 1998 yang menyatakan bahawa pemimpin sekolah yang berkesan perlu mempunyai kemahiran komunikasi yang cemerlang, membina hubungan yang baik dengan sekitarnya, menerima tanggungjawab dengan professional, membuat keputusan berdasarkan persetujuan bersama serta beberapa lagi kemahiran personal yang lain.

Satu kajian yang dijalankan oleh Ab. Majid (2008) terhadap persepsi guru di sekolah mendapati bahawa gaya kepimpinan berorientasikan kejayaan adalah gaya kepimpinan yang paling dominan diikuti gaya kepimpinan partisipatif dan menyokong manakalah gaya kepimpinan mengarah adalah yang paling akhir. Kajian ini membuktikan bahawa gaya kepimpinan instruksional adalah kepimpinan yang paling berkesan untuk diamalkan di sekolah. Kepimpinan instruksional adalah usaha-usaha yang diambil oleh pemimpin sekolah untuk melakukan inovasi dalam kurikulum serta memperkembangkan proses pembelajaran dengan tujuan menjayakan matlamat sekolah (Hussein, 1998). Justeru, gaya kepimpinan guru besar adalah penting dalam mencapai kejayaan di sesebuah sekolah. 
Sebagai pelaksana, kualiti kerja yang dipamerkan oleh guru-guru bergantung kepada motivasi mereka untuk melaksanakan tugasan dan arahan yang diberikan oleh guru. Sekiranya guru mempunyai motivasi yang tinggi, maka akan terhasillah tugasan yang baik dan sempurna, begitu juga sebaliknya. Hal ini dipersetujui oleh Teow Chong \& Yim Lean (2005) yang menyatakan bahawa kekuatan motivasi individu akan menyumbang kepada pembentukan tenaga kerja yang kolektif. Oleh yang demikian, dalam melaksana apa jua tugasan di sekolah, guru besar harus bijak dalam memelihara motivasi guru demi meningkatkan kecemerlangan dan kualiti perkhidmatan yang diberikan.

\section{Sorotan Literatur}

Guru besar merupakan individu yang berperanan penting dalam mengendalikan organisasi pentadbiran di sekolah. Banyak kajian yang telah dijalankan membuktikan bahawa pemboleh ubah pengurusan seperti kepimpinan guru besar memberi pengaruh yang besar terhadap kualiti pendidikan dan pencapaian akademik sesebuah sekolah yang ditadbir (Qamal Taqreem, 2018). Hal ini turut dibuktikan melalui kajian oleh Ramlee \& Sani (2010) bahawa pengurusan dan kepimpinan guru besar merupakan faktor utama yang menentukan kejayaan sesebuah organisasi. Pentadbiran yang berkesan juga akan mewujudkan sekolah yang mempunyai peranan yang baik bukan sahaja dalam bidang pentadbiran malahan dalam semua bidang seperti pembangunan kurikulum dan kegiatan akademik (Sani, 2013).

Reformasi dalam pendidikan merupakan satu perkara yang kerap berlaku di kebanyakan negara dengan tujuan untuk menambahbaik sistem pendidikan yang sedia ada (Izham \& Norziana, 2015). Demikian juga hal nya yang berlaku dalam sistem pendidikan di Malaysia. Perkembangan terkini sistem pendidikan negara telah menunjukkan berlakunya reformasi pendidikan yang amat ketara di pelbagai peringkat sama ada di peringkat kementerian, jabatan dan di sekolah (Nurul Syuhaida, et. al., 2019). Hal ini termasuklah penubuhan Institut Aminuddin Baki (IAB) sebagai sebuah institusi latihan kepimpinan dan pengurusan pendidikan bagi membangunkan keupayaan pengurus dan pemimpin pendidikan di semua peringkat Kementerian Pendidikan Malaysia (KPM).

Program Kelayakan Profesional Pemimpin Pendidikan Kebangsaan (National Professional Qualification for Educational Leaders - NPQEL) dimulakan pada tahun 1999 di IAB sebagai salah satu usaha daripada KPM untuk melahirkan golongan pemimpin yang berwibawa serta mampu untuk mentadbir kepimpinan sekolah dengan baik dan berkesan. Perubahan demi perubahan dilakukan dalam mod pembelajaran NPQEL agar seiring dengan perubahan pendidikan semasa. Terkini, Anjakan ke-5 dalam Pelan Pembangunan Pendidikan Malaysia 2013-2025 turut menegaskan keperluan untuk bakal pemimpin pelapis di sekolah untuk menghadiri latihan NPQEL (PPPM: E-20).

Apakah bidang tugas guru besar di sekolah sehingga peranan mereka dilihat begitu memberi kesan terhadap sekolah yang dipimpin? Hussein (1993) menyatakan bahawa peranan yang perlu dimainkan oleh guru besar itu meliputi tiga aspek iaitu sebagai pengurus, pentadbir dan pemimpin. Manakala Sani (2013) menyatakan peranan guru besar dalam konteks pengurusan sekolah adalah sebagai perancang, penggubal dan pembuat dasar. Tugas mereka meliputi tugas-tugas sebagai peneraju, pembimbing, pendorong (Standard 1 SKPMg2; 2016), pentadbir, pengurus, penyelia, pengarah, pewakil, pemudah cara, penyelaras, pemberangsang dan penilai. Bagi melaksanakan peranan dan tanggungjawab yang demikian, guru besar perlu menggerakkan segala bentuk sumber dan modal insan yang ada di sekolah terutamanya guru supaya guru-guru dapat berkhidmat dengan komited dan efektif (Lokman Tahir, 2008).

Sistem Pemastian Peningkatan Standard Tinggi Kualiti Pendidikan (SPPSTKP) atau juga disebut sebagai Standard Tinggi Kualiti Pendidikan (STKP) yang dilindungi oleh Akta Pendidikan 1996 subseksyen 117(a) telah memperuntukkan tanggungjawab kepada Ketua Nazir Sekolah (KNS) untuk memastikan taraf atau lebih dikenali sebagai standard dalam pengajaran yang memuaskan diwujudkan dan dikekalkan di institusi pendidikan. Sehubungan itu, Jemaah Nazir dan Jaminan Kualiti (JNJK) telah memperkenalkan satu mekanisme yang lebih sistematik dalam menetapkan satu standard sebagai usaha untuk meningkatkan kualiti pendidikan yang kini dikenali sebagai Standard Kualiti Pendidikan 
Malaysia Gelombang 2 (SKPMg2) setelah melalui beberapa perubahan bagi memastikan ianya merupakan satu dokumen standard yang benar-benar menepati keperluan kualiti pendidikan hari ini.

SKPMg2 dihasilkan untuk memastikan kelangsungan transformasi pendidikan negara selaras dengan keperluan pendidikan bertaraf global. Penghayatan dan pembudayaan SKPMg2 dapat menjadi pemangkin untuk merealisasikan aspirasi pendidikan negara serta memartabatkan kecemerlangan pendidikan negara (Mahdzir Khalid, 2017). Mantan Ketua Pengarah Pendidikan Malaysia melalui Panduan SKPMg2 yang dihasilkan oleh JNJK (2017) turut menyatakan bahawa SKPMg2 disediakan sebagai satu usaha untuk memastikan institusi pendidikan negara mempunyai standard yang boleh diiktiraf dan dijadikan penandaarasan oleh negara luar. Menurut beliau lagi, SKPMg2 seharusnya dijadikan sebagai Milik Sekolah dalam menentukan keberkesanan pengurusan di bawah kepimpinan sekolah. Oleh yang demikian, adalah penting agar dokumen SKPMg2 dihayati dan dipatuhi demi kecemerlangan pendidikan negara.

Perkataan motivasi berasal dari perkataan Latin iaitu 'movere' yang bermaksud 'bergerak' (Steers dan Porter, 1991). Sementara menurut MacIntyre, MacKinnon \& Clement (2009), motivasi merupakan satu konsep yang menjelaskan apa jua kekuatan yang terdapat dalam diri seseorang yang membawa kepada perilaku serta melibatkan kepentingan, keseuaian, jangkaan kejayaan atau kegagalan, kepercayaan dalam ganjaran yang diperolehi, keputusan dalam keterlibatan, kegigihan serta tahap aktiviti yang tinggi. Justeru, motivasi digambarkan sebagai 'enjin' yang menggerakkan 'sistem'. Istilah motivasi telah digunakan lebih daripada satu abad dan merupakan antara konsep dalam psikologi yang sentiasa menjadi bahan perbincangan.

Individu yang mempunyai motivasi kerja yang tinggi akan memberikan juga komitmen yang tinggi terhadap pekerjaan yang mereka lakukan (Ofojebe \& Ezugoh, 2010). Hal ini kerana seseorang yang mempunyai motivasi kerja yang tinggi tidak akan cepat berputus asa serta dapat memberikan penjelasan tentang mengapa mereka melakukan sesuatu atau melakukan pekerjaan tersebut (BeltránMartín \& Bou-Llusar, 2018). Demikian juga dalam bidang pendidikan. Seorang guru yang mempunyai motivasi kerja yang tinggi sekaligus akan mempunyai komitmen dan semangat yang tinggi untuk bekerja dan melaksanakan semua tugas mereka tugas dengan sebaiknya (Muhammad Ruslan, 2020). Oleh itu, motivasi kerja memainkan peranan penting dalam mempengaruhi tahap kemampuan guru untuk melaksanakan tugas dan fungsinya di sekolah (Kemelimeda et al., 2018).

Teori motivasi pencapaian oleh McClelland (1978) dalam Abdul Rahman (1997) mengatakan bahawa motivasi individu akan meningkat sekiranya individu tersebut dimotivasikan dan memahami unsurunsur motivasi serta melibatkan diri secara aktif dalam usaha itu. Hal ini bererti bahawa proses motivasi itu bertindak secara dua hala dengan kedua-dua pihak mestilah saling berperanan untuk memberi dan menerima seperti yang dinyatakan oleh Anthony, Said, Mohamad, \& Mokhtar (2015) bahawa kejayaan, keberkesanan atau kegagalan perubahan sekolah adalah dikaitkan dengan kepimpinan peneraju sekolah. Perubahan tidak akan berkesan dalam organisasi pendidikan kecuali pemimpin sekolah itu sendiri melalui kepimpinannya, memulakan secara kompetitif (Sentočnik, Sales \& Richardson, 2016).

\section{Metod Kajian}

Kajian kuantitatif ini adalah kajian bukan eksperimen iaitu berbentuk kajian korelasi. Dalam kajian ini, kajian korelasi digunakan untuk mengkaji hubungan antara pemboleh ubah bebas iaitu tahap pematuhan Standard 1 SKPMg2 dalam kalangan guru besar dengan tahap motivasi guru di sekolah yang menjadi pemboleh ubah bersandar. Seramai 120 orang guru dari sekolah-sekolah rendah di sekitar negeri Johor telah dipilih sebagai peserta kajian.

\section{Instrumen Kajian}

Sebanyak 53 item soal selidik berkenaan tahap pematuhan Standard 1 SKPMg2 dan motivasi guru telah diedarkan kepada peserta kajian. Soal selidik ini menggunakan skala Likert dengan lima skala 
DOI: https://doi.org/10.47405/mjssh.v6i6.824

iaitu dari 1 (Sangat Tidak Setuju) hingga 5 (Sangat Setuju) bagi item berkaitan tahap pematuhan Standard 1 SKPMg2 dan skala Guttman iaitu Ya dan Tidak bagi item berkaitan tahap motivasi guru.

Soal selidik ini terbahagi kepada tiga bahagian iaitu Bahagian A, B dan C. Bahagian A merupakan bahagian maklumat peserta kajian. Manakala Bahagian B adalah berkaitan dengan tahap pematuhan Standard 1 SKPMg2 dalam kalangan guru besar yang mengandungi 43 item sementara 12 item dalam Bahagian $\mathrm{C}$ berfokus kepada tahap motivasi guru

\section{Analisis Kajian}

Data yang diperoleh telah dianalisis dengan menggunakan program Statistical Package for Social Science version 23. Dapatan daripada kedua-dua soal selidik dianalisis menggunakan ujian nonparametric. Manakala ujian kolerasi Spearman digunakan untuk melihat hubungan antara tahap pematuhan Standard 1 SKPMg2 dalam kalangan guru besar dengan motivasi guru.

\section{Hasil Kajian}

\section{Analisis Keseluruhan Hubungan Antara Tahap Pematuhan Standard 1 Skpmg2 Dalam Kalangan Guru Besar Dengan Motivasi Guru}

Dapatan keseluruhan ujian kolerasi yang dijalankan mendapati bahawa tahap pematuhan Standard 1 SKPMg2 dalam kalangan guru besar berhubungan secara positif dan signifikan dengan tahap motivasi guru di mana nilai $r=0.985$ manakala nilai $\mathrm{p}$ adalah 0.000 iaitu tidak melebihi nilai alpha 0.01 . Hal ini membuktikan bahawa kekuatan di antara kedua-dua pemboleh ubah ini adalah sangat kuat berpandukan kepada kategori kekuatan hubungan kolerasi yang dinyatakan di atas.

Sehubungan itu, keputusan ujian korelasi ini adalah menolak H_0 iaitu terdapat hubungan yang signifikan di antara tahap pematuhan Standard 1 SKPMg2 dalam kalangan guru besar dengan motivasi guru.

Jadual 1: Hubungan Antara Tahap Pematuhan Standard 1 Dalam Kalangan Guru Besar Dengan Tahap Motivasi Guru

\begin{tabular}{lll} 
& \multicolumn{2}{l}{ Tahap Pematuhan Standard 1 SKPMg2 dalam kalangan Guru Besar } \\
\cline { 2 - 3 } & Nilai $\boldsymbol{r}$ & P \\
\hline $\begin{array}{l}\text { Tahap Motivasi } \\
\text { Guru }\end{array}$ & 0.985 & 0.000
\end{tabular}

\section{Analisis Hubungan Antara Setiap Item Bagi Tahap Pematuhan Standard 1 SKPMg2 Dalam Kalangan Guru Besar Dengan Motivasi Guru}

Dapatan ujian kolerasi yang dijalankan mendapati bahawa item 1 tahap pematuhan Standard 1 SKPMg2 dalam kalangan guru besar berhubungan secara negatif dan tidak signifikan dengan item 1 tahap motivasi guru di mana nilai $\mathrm{r}=-0.071$ manakala nilai $\mathrm{p}$ adalah 0.441 iaitu melebihi nilai alpha 0.01. Hal ini membuktikan bahawa kekuatan di antara kedua-dua pemboleh ubah ini adalah sangat lemah berpandukan kepada kategori kekuatan hubungan kolerasi yang dinyatakan di atas.

Sehubungan itu, keputusan ujian korelasi ini adalah gagal menolak hipotesis nol iaitu tidak terdapat hubungan yang signifikan di antara item 1 tahap pematuhan Standard 1 SKPMg2 dalam kalangan guru besar dengan item 1 motivasi guru. 
DOI: https://doi.org/10.47405/mjssh.v6i6.824

Jadual 2: Hubungan Antara Item 1 Tahap Pematuhan Standard 1 Dalam Kalangan Guru Besar Dengan Item 1 Tahap Motivasi Guru

\begin{tabular}{lll}
\hline & \multicolumn{2}{l}{$\begin{array}{l}\text { Item 1 Tahap Pematuhan Standard 1 SKPMg2 dalam kalangan Guru } \\
\text { Besar }\end{array}$} \\
\cline { 2 - 3 } & Nilai $\boldsymbol{r}$ & P \\
\hline $\begin{array}{l}\text { Item 1 Tahap } \\
\text { Motivasi Guru }\end{array}$ & -0.071 & 0.441 \\
\hline
\end{tabular}

Jadual 3: Hubungan Antara Item 2 Tahap Pematuhan Standard 1 Dalam Kalangan Guru Besar Dengan Item 2 Motivasi Guru

\begin{tabular}{lll}
\hline & \multicolumn{2}{l}{ Item 2 Tahap Pematuhan Standard 1 } \\
\cline { 2 - 3 } & Nilai $\boldsymbol{r}$ & P \\
\hline $\begin{array}{l}\text { Item 2 Tahap } \\
\text { Motivasi Guru }\end{array}$ & 0.489 & 0.000 \\
\hline
\end{tabular}

Dapatan ujian kolerasi yang dijalankan mendapati bahawa item 2 tahap pematuhan Standard 1 SKPMg2 dalam kalangan guru besar berhubungan secara positif dan signifikan dengan item 2 motivasi guru di mana nilai $\mathrm{r}=0.489$ manakala nilai $\mathrm{p}$ adalah 0.000 iaitu tidak melebihi nilai alpha 0.01. Hal ini membuktikan bahawa kekuatan di antara kedua-dua pemboleh ubah ini adalah sederhana berpandukan kepada kategori kekuatan hubungan kolerasi yang dinyatakan di atas.

Sehubungan itu, keputusan ujian korelasi ini adalah menolak hipotesis nol iaitu terdapat hubungan yang signifikan di antara item 2 tahap pematuhan Standard 1 SKPMg2 dalam kalangan guru besar dengan item 2 tahap motivasi guru.

Jadual 4: Hubungan Antara Item 3 Tahap Pematuhan Standard 1 Dalam Kalangan Guru Besar Dengan Item 3 Motivasi Guru

\begin{tabular}{lll}
\hline & \multicolumn{2}{l}{ Item 3 Tahap Pematuhan Standard 1 } \\
\cline { 2 - 3 } & Nilai $\boldsymbol{r}$ & P \\
\hline $\begin{array}{l}\text { Item 3 Tahap } \\
\text { Motivasi Guru }\end{array}$ & 0.660 & 0.000 \\
\hline
\end{tabular}

Dapatan ujian kolerasi yang dijalankan mendapati bahawa item 3 tahap pematuhan Standard 1 SKPMg2 dalam kalangan guru besar berhubungan secara positif dan signifikan dengan motivasi guru di mana nilai $r=0.660$ manakala nilai $\mathrm{p}$ adalah 0.000 iaitu tidak melebihi nilai alpha 0.01 . Hal ini membuktikan bahawa kekuatan di antara kedua-dua pemboleh ubah ini adalah kuat berpandukan kepada kategori kekuatan hubungan kolerasi yang dinyatakan di atas.

Sehubungan itu, keputusan ujian korelasi ini adalah menolak hipotesis nol iaitu terdapat hubungan yang signifikan di antara item 3 tahap pematuhan Standard 1 SKPMg2 dalam kalangan guru besar dengan item 3 tahap motivasi guru.

Jadual 5: Hubungan Antara Item 4 Tahap Pematuhan Standard 1 Dalam Kalangan Guru Besar Dengan Item 4 Motivasi Guru

\begin{tabular}{lll}
\hline & \multicolumn{2}{l}{ Item 4 Tahap Pematuhan Standard 1 dalam kalangan Guru Besar } \\
\cline { 2 - 3 } & Nilai $\boldsymbol{r}$ & $\mathbf{P}$ \\
\hline $\begin{array}{l}\text { Item 4 Tahap } \\
\text { Motivasi Guru }\end{array}$ & 0.837 & 0.000 \\
\hline
\end{tabular}


Dapatan ujian kolerasi yang dijalankan mendapati bahawa item 4 tahap pematuhan Standard 1 SKPMg2 dalam kalangan guru besar berhubungan secara positif dan signifikan dengan item 4 tahap motivasi guru di mana nilai $\mathrm{r}=0.837$ manakala nilai $\mathrm{p}$ adalah 0.000 iaitu tidak melebihi nilai alpha 0.01. Hal ini membuktikan bahawa kekuatan di antara kedua-dua pemboleh ubah ini adalah sangat kuat berpandukan kepada kategori kekuatan hubungan kolerasi yang dinyatakan di atas.

Sehubungan itu, keputusan ujian korelasi ini adalah menolak hipotesis nol iaitu terdapat hubungan yang signifikan di antara item 4 tahap pematuhan Standard 1 SKPMg2 dalam kalangan guru besar dengan item 4 tahap motivasi guru.

Jadual 6: Hubungan Antara Item 5 Tahap Pematuhan Standard 1 Dalam Kalangan Guru Besar Dengan Item 5 Motivasi Guru

\begin{tabular}{lll}
\hline & \multicolumn{2}{l}{ Item 5 Tahap Pematuhan Standard 1 dalam kalangan Guru Besar } \\
\cline { 2 - 3 } & Nilai $\boldsymbol{r}$ & $\mathbf{P}$ \\
\hline $\begin{array}{l}\text { Item 5 Tahap } \\
\text { Motivasi Guru }\end{array}$ & 0.772 & 0.000 \\
\hline
\end{tabular}

Dapatan ujian kolerasi yang dijalankan mendapati bahawa item 5 tahap pematuhan Standard 1 SKPMg2 dalam kalangan guru besar berhubungan secara positif dan signifikan dengan item 5 motivasi guru di mana nilai $\mathrm{r}=0.772$ manakala nilai $\mathrm{p}$ adalah 0.000 iaitu tidak melebihi nilai alpha 0.01. Hal ini membuktikan bahawa kekuatan di antara kedua-dua pemboleh ubah ini adalah kuat berpandukan kepada kategori kekuatan hubungan kolerasi yang dinyatakan di atas.

Sehubungan itu, keputusan ujian korelasi ini adalah menolak hipotesis nol iaitu terdapat hubungan yang signifikan di antara item 5 tahap pematuhan Standard 1 SKPMg2 dalam kalangan guru besar dengan item 5 tahap motivasi guru.

Jadual 7: Hubungan Antara Item 6 Tahap Pematuhan Standard 1 Dalam Kalangan Guru Besar Dengan Item 6 Motivasi Guru

\begin{tabular}{lll}
\hline & \multicolumn{2}{c}{ Item 6 Tahap Pematuhan Standard 1 dalam kalangan Guru Besar } \\
\cline { 2 - 3 } & Nilai $\boldsymbol{r}$ & $\mathbf{P}$ \\
\hline $\begin{array}{l}\text { Item 6 Tahap } \\
\text { Motivasi Guru }\end{array}$ & 0.871 & 0.000 \\
\hline
\end{tabular}

Dapatan ujian kolerasi yang dijalankan mendapati bahawa item 6 tahap pematuhan Standard 1 SKPMg2 dalam kalangan guru besar berhubungan secara positif dan signifikan dengan item 6 motivasi guru di mana nilai $\mathrm{r}=0.871$ manakala nilai $\mathrm{p}$ adalah 0.000 iaitu tidak melebihi nilai alpha 0.01. Hal ini membuktikan bahawa kekuatan di antara kedua-dua pemboleh ubah ini adalah sangat kuat berpandukan kepada kategori kekuatan hubungan kolerasi yang dinyatakan di atas.

Sehubungan itu, keputusan ujian korelasi ini adalah menolak hipotesis nol iaitu terdapat hubungan yang signifikan di antara item 6 tahap pematuhan Standard 1 SKPMg2 dalam kalangan guru besar dengan item 6 tahap motivasi guru.

Jadual 8: Hubungan Antara Item 7 Tahap Pematuhan Standard 1 Dalam Kalangan Guru Besar Dengan Item 7 Motivasi Guru

\begin{tabular}{lll}
\hline & \multicolumn{2}{l}{ Item 7 Tahap Pematuhan Standard 1 dalam kalangan Guru Besar } \\
\cline { 2 - 3 } & Nilai $\boldsymbol{r}$ & $\mathbf{P}$ \\
\hline $\begin{array}{l}\text { Item 7 Tahap } \\
\text { Motivasi Guru }\end{array}$ & 0.774 & 0.000 \\
\hline
\end{tabular}


Dapatan ujian kolerasi yang dijalankan mendapati bahawa item 7 tahap pematuhan Standard 1 SKPMg2 dalam kalangan guru besar berhubungan secara positif dan signifikan dengan item 7 motivasi guru di mana nilai $\mathrm{r}=0.774$ manakala nilai $\mathrm{p}$ adalah 0.000 iaitu tidak melebihi nilai alpha 0.01. Hal ini membuktikan bahawa kekuatan di antara kedua-dua pemboleh ubah ini adalah kuat berpandukan kepada kategori kekuatan hubungan kolerasi yang dinyatakan di atas.

Sehubungan itu, keputusan ujian korelasi ini adalah menolak hipotesis nol iaitu terdapat hubungan yang signifikan di antara item 7 tahap pematuhan Standard 1 SKPMg2 dalam kalangan guru besar dengan item 7 tahap motivasi guru.

Jadual 9: Hubungan Antara Item 8 Tahap Pematuhan Standard 1 Dalam Kalangan Guru Besar Dengan Item 8 Motivasi Guru

\begin{tabular}{lll}
\hline & \multicolumn{2}{l}{ Item 8 Tahap Pematuhan Standard 1 dalam kalangan Guru Besar } \\
\cline { 2 - 3 } & Nilai $\boldsymbol{r}$ & $\mathbf{P}$ \\
\hline $\begin{array}{l}\text { Item 8 Tahap } \\
\text { Motivasi Guru }\end{array}$ & 0.791 & 0.000 \\
\hline
\end{tabular}

Dapatan ujian kolerasi yang dijalankan mendapati bahawa item 8 tahap pematuhan Standard 1 SKPMg2 dalam kalangan guru besar berhubungan secara positif dan signifikan dengan item 8 motivasi guru di mana nilai $\mathrm{r}=0.791$ manakala nilai $\mathrm{p}$ adalah 0.000 iaitu tidak melebihi nilai alpha 0.01. Hal ini membuktikan bahawa kekuatan di antara kedua-dua pemboleh ubah ini adalah sangat kuat berpandukan kepada kategori kekuatan hubungan kolerasi yang dinyatakan di atas.

Sehubungan itu, keputusan ujian korelasi ini adalah menolak hipotesis nol iaitu terdapat hubungan yang signifikan di antara item 8 tahap pematuhan Standard 1 SKPMg2 dalam kalangan guru besar dengan item 8 tahap motivasi guru.

Jadual 10: Hubungan Antara Item 9 Tahap Pematuhan Standard 1 Dalam Kalangan Guru Besar Dengan Item 9 Motivasi Guru

\begin{tabular}{lll}
\hline & \multicolumn{2}{l}{ Item 9 Tahap Pematuhan Standard 1 dalam kalangan Guru Besar } \\
\cline { 2 - 3 } & Nilai $\boldsymbol{r}$ & $\mathbf{P}$ \\
\hline $\begin{array}{l}\text { Item 9 Tahap } \\
\text { Motivasi Guru }\end{array}$ & 0.854 & 0.000 \\
\hline
\end{tabular}

Dapatan ujian kolerasi yang dijalankan mendapati bahawa item 9 tahap pematuhan Standard 1 SKPMg2 dalam kalangan guru besar berhubungan secara positif dan signifikan dengan item 9 motivasi guru di mana nilai $\mathrm{r}=0.854$ manakala nilai $\mathrm{p}$ adalah 0.000 iaitu tidak melebihi nilai alpha 0.01. Hal ini membuktikan bahawa kekuatan di antara kedua-dua pemboleh ubah ini adalah sangat kuat berpandukan kepada kategori kekuatan hubungan kolerasi yang dinyatakan di atas.

Sehubungan itu, keputusan ujian korelasi ini adalah menolak hipotesis nol iaitu terdapat hubungan yang signifikan di antara item 9 tahap pematuhan Standard 1 SKPMg2 dalam kalangan guru besar dengan item 9 tahap motivasi guru.

Jadual 11: Hubungan Antara Item 10 Tahap Pematuhan Standard 1 Dalam Kalangan Guru Besar Dengan Item 10 Motivasi Guru

\begin{tabular}{lll}
\hline & \multicolumn{2}{l}{ Item 10 Tahap Pematuhan Standard 1 dalam kalangan Guru Besar } \\
\cline { 2 - 3 } & Nilai $\boldsymbol{r}$ & $\mathbf{P}$ \\
\hline $\begin{array}{l}\text { Item 10 Tahap } \\
\text { Motivasi Guru }\end{array}$ & 0.829 & 0.000 \\
\hline
\end{tabular}

Dapatan ujian kolerasi yang dijalankan mendapati bahawa item 10 tahap pematuhan Standard 1 SKPMg2 dalam kalangan guru besar berhubungan secara positif dan signifikan dengan item 10 
motivasi guru di mana nilai $\mathrm{r}=0.829$ manakala nilai $\mathrm{p}$ adalah 0.000 iaitu tidak melebihi nilai alpha 0.01. Hal ini membuktikan bahawa kekuatan di antara kedua-dua pemboleh ubah ini adalah sangat kuat berpandukan kepada kategori kekuatan hubungan kolerasi yang dinyatakan di atas.

Sehubungan itu, keputusan ujian korelasi ini adalah menolak hipotesis nol iaitu terdapat hubungan yang signifikan di antara item 10 tahap pematuhan Standard 1 SKPMg2 dalam kalangan guru besar dengan item 10 tahap motivasi guru.

Jadual 12: Hubungan Antara Item 11 Tahap Pematuhan Standard 1 Dalam Kalangan Guru Besar Dengan Item 11 Motivasi Guru

\begin{tabular}{lll}
\hline & \multicolumn{2}{l}{ Item 11 Tahap Pematuhan Standard 1 dalam kalangan Guru Besar } \\
\cline { 2 - 3 } & Nilai $\boldsymbol{r}$ & $\mathbf{P}$ \\
\hline $\begin{array}{l}\text { Item 11 Tahap } \\
\text { Motivasi Guru }\end{array}$ & 0.734 & 0.000 \\
\hline
\end{tabular}

Dapatan ujian kolerasi yang dijalankan mendapati bahawa item 11 tahap pematuhan Standard 1 SKPMg2 dalam kalangan guru besar berhubungan secara positif dan signifikan dengan item 11 motivasi guru di mana nilai $\mathrm{r}=0.734$ manakala nilai $\mathrm{p}$ adalah 0.000 iaitu tidak melebihi nilai alpha 0.01. Hal ini membuktikan bahawa kekuatan di antara kedua-dua pemboleh ubah ini adalah kuat berpandukan kepada kategori kekuatan hubungan kolerasi yang dinyatakan di atas.

Sehubungan itu, keputusan ujian korelasi ini adalah menolak hipotesis nol iaitu terdapat hubungan yang signifikan di antara item 11 tahap pematuhan Standard 1 SKPMg2 dalam kalangan guru besar dengan item 11 tahap motivasi guru.

Jadual 13: Hubungan Antara Item 12 Tahap Pematuhan Standard 1 Dalam Kalangan Guru Besar Dengan Item 12 Motivasi Guru

\begin{tabular}{lll}
\hline & \multicolumn{2}{c}{ Item 12 Tahap Pematuhan Standard 1 dalam kalangan Guru Besar } \\
\cline { 2 - 3 } & Nilai $\boldsymbol{r}$ & P \\
\hline $\begin{array}{l}\text { Item 12 Tahap } \\
\text { Motivasi Guru }\end{array}$ & 0.752 & 0.000 \\
\hline
\end{tabular}

Dapatan ujian kolerasi yang dijalankan mendapati bahawa item 12 tahap pematuhan Standard 1 SKPMg2 dalam kalangan guru besar berhubungan secara positif dan signifikan dengan item 12 motivasi guru di mana nilai $\mathrm{r}=0.752$ manakala nilai $\mathrm{p}$ adalah 0.000 iaitu tidak melebihi nilai alpha 0.01. Hal ini membuktikan bahawa kekuatan di antara kedua-dua pemboleh ubah ini adalah sangat kuat berpandukan kepada kategori kekuatan hubungan kolerasi yang dinyatakan di atas.

Sehubungan itu, keputusan ujian korelasi ini adalah menolak hipotesis nol iaitu terdapat hubungan yang signifikan di antara item 12 tahap pematuhan Standard 1 SKPMg2 dalam kalangan guru besar dengan item 12 tahap motivasi guru.

\section{Perbincangan Kajian}

Secara keseluruhannya, keputusan ujian kolerasi yang dijalankan menunjukkan nilai $\mathrm{r}$ adalah 0.985 dengan $\mathrm{p}$ adalah $0.000<0.01$. Hal ini jelas menunjukkan bahawa hubungan di antara kedua-dua pemboleh ubah ini adalah sangat kuat. Oleh yang demikian, pengkaji telah membuktikan bahawa tahap pematuhan guru besar terhadap aspek-aspek yang terkandung dalam Standard 1 SKPMg2 memberi pengaruh yang sangat kuat terhadap motivasi guru di sekolah.

Dokumen Standard Kualiti Pendidikan Malaysia Gelombang 2 (SKPMg2) dihasilkan dengan tujuan untuk memastikan transformasi pendidikan negara adalah seiring dengan keperluan pendidikan bertaraf global. Dokumen yang komprehensif ini menekankan perubahan pertama yang perlu dilakukan bagi 
memastikan misi dan visi Kementerian Pendidikan Malaysia (KPM) dapat dicapai adalah melalui kepimpinan sekolah. Justeru, keputusan hubungan yang sangat kuat ini membuktikan bahawa Standard 1 SKPMg2 adalah khusus untuk memastikan bahawa semua pemimpin sekolah melaksanakan perkaraperkara asas dalam disiplin sekolah selain memastikan setiap daripada mereka menjalankan peranan sebagai peneraju, pembimbing dan pendorong kepada warga sekolah dengan maksima seperti mana yang dinyatakan dalam dokumen Standard 1 SKPMg2.

Tidak hanya itu, keputusan hubungan korelasi dalam kajian ini seharusnya turut menjadi pemangkin kepada guru besar untuk lebih mematuhi setiap aspek yang terkandung dalam Standard 1 SKPMg2 dalam usaha untuk meningkatkan motivasi kerja guru di sekolah sekaligus dapat menambahkan kelancaran pengurusan sekolah dalam pelbagai aspek. Keputusan ujian korelasi yang ditunjukkan melalui tiga item pada aspek 'Guru Besar sebagai Pendorong' iaitu pada item 9; sangat kuat, item 10; kuat dan item 11; sangat kuat membuktikan bahawa peranan guru besar sebagai pendorong kepada guru-guru memberikan impak yang sangat besar terhadap motivasi guru. Hal ini adalah seiring dengan definisi 'motivasi' dalam Kamus Dewan Edisi Ke-4 iaitu motivasi adalah sesuatu yg membuat atau mendorong seseorang berusaha atau melaku-kan sesuatu dgn penuh minat. Justeru, adalah tepat seperti yang dinyatakan oleh Ikon Pemimpin Negeri Kedah 2020 iaitu Cikgu Mohd Nizam Saidin, Guru Besar SK Dato' Wan Kemara, Changlun yang menyatakan bahawa guru-guru menjadi lebih bersemangat untuk bekerja dan melahirkan murid yang cemerlang dalam semua bidang apabila diberi dorongan dan motivasi oleh guru besar.

Hal ini berbeza dengan dapatan daripada ujian korelasi yang dijalankan pada item 1 yang menunjukkan keputusan kekuatan hubungan yang sangat lemah dan item 2 yang menunjukkan keputusan kekuatan hubungan yang sederhana. Kedua-dua item ini berada pada aspek 'Guru Besar sebagai Peneraju'. Dalam hal ini, keputusan ujian membuktikan bahawa perancangan guru besar terhadap hala tuju sekolah tidak mempengaruhi motivasi guru untuk bekerja di sekolah. Namun demikian, keputusan ini tidak seharusnya dipandang enteng oleh guru besar. Hal ini kerana perancangan dan hala tuju sekolah adalah perkara asas dalam pengurusan dan pentadbiran guru besar. Perancangan dan hala tuju merupakan satu alat yang berupaya untuk memastikan guru besar dapat mengurus dan mentadbir sekolah dengan betul selain memastikan guru besar mempunyai wawasan yang tersendiri sebagai pemimpin sekolah. Oleh sebab itu, adalah penting agar guru besar dapat mematuhi dengan sebaiknya semua aspek yang terkandung dalam Standard 1 SKPMg2 agar pengoperasian sekolah dapat dijalankan dengan sempurna selain dapat membuktikan keupayaan guru besar itu sendiri sebagai peneraju sekolah.

\section{Kesimpulan}

Kesimpulannya, kajian ini telah memberikan pandangan tentang pengaruh tahap pematuhan guru besar terhadap Standard 1 SKPMg2 dengan motivasi guru di sekolah. Hal ini dapat dibuktikan melalui pengalaman dan pengamatan guru terhadap peranan guru besar di sekolahnya sebagai peneraju, pembimbing dan pendorong berdasarkan soal selidik yang telah dijalankan dan dianalis. Hasilnya, tahap pematuhan Standard 1 SKPMg2 dalam kalangan guru besar memberi pengaruh yang sangat kuat dengan motivasi guru di sekolah.

\section{Rujukan}

Abdul Majid Salleh. (2008). Persepsi guru-guru terhadap gaya kepimpinan guru besar di empat buah sekolah rendah di daerah hulu terengganu. Tesis sarjana: UTM.

Abdul Rahman Aziz. (1997). Motivasi dan pembangunan diri. Kuala Lumpur: Utusan Publications \& Distributors Sdn. Bhd.

Abdul Said Ambotang. (2003). Kajian persepsi hubungan kepimpinan pengetua dengan tahap motivasi guru sekolah menengah di daerah beaufort, sabah. Tesis sarjana: Universiti Malaysia Sabah. 
Ahmad Jawahir Tugimin (2005). Perkaitan antara kepuasan kerja dengan tekanan kerja dalam kalangan tenaga pengajar teknikal dan industri di kolej universiti malaysia. Kertas kerja: Universiti Teknikal Malaysia Melaka.

Azizi Yahya, Halimah Maalip, Noordin Yahaya \& Lim Ting Theng. (2011). Hubungan gaya kepimpinan guru besar dengan faktor-faktor kepimpinan di sekolah cemerlang. Journal of educational management, Vol. 1, 48-70.

Beltrán-Martín, I., \& Bou-Llusar, J. C. (2018). Examining the central role of employee abilities, motivation, and opportunities to participate in the relationship between HR bundles and employee performance. BRQ Business Research Quarterly, 21(2), 99-110.

Bity Salwana Alias, Ahmad Basri Md. Yussof, Ramlee Mustapha \& Mohammed Sani Ibrahim. (2010). Analisis kompetensi pengetua berdasarkan kualiti peribadi, pengetahuan, kemahiran dan amalan dalam bidang pengurusan sekolah menengah malaysia. Jurnal pendidikan malaysia, 35(2), 31-41.

Dalila Abdul Muttalip, RuslinAmir \& Salleh Amat. (2021). Hubungan tingkah laku kepimpinan guru besar dan beban kerja guru terhadap prestasi kerja guru. Jurnal dunia pengurusan, 3(1), 30-40.

Dayangku Rodzianah binti Awangku Amin \& Mohd Izham bin Mohd Hamzah. (2021). Tahap amalan kepimpinan instruksional guru besar dan hubungannya dengan tahap komitmen guru. Malaysian journal of social sciences and humanities (MJSSH), 6(2), 135-151.

Diah Pranitasari. (2020). The influence of effective leadership and organizational trust to teacher's work motivation and organizational commitment. Media ekonomi dan manajemen, 35(1), 75-91.

Ebrahimi M. \& K. Mohamadkhani. (2014). The relationship between organizational climate and job involvement among teachers of high schools in delijan city (Iran). International journal of management and business research, 4(1), 65-72.

Gizem Engin. (2020). An examination of primary school students' academic achievements and motivation in terms of parents' attitudes, teacher motivation, teacher self-efficacy and leadership approach. International journal of progressive education, 16(1), 257-276.

GobinathanVijian \& Jamalul Lail Abdul Wahab. (2020). Kepimpinan transformasional guru besar dankepuasan kerja guru-guru di sekolah jeniskebangsaan tamil zon kajang. international journal of education and pedagogy, 2(2), 18-31.

Hallinger, P. (2012). A data-driven approach to assess and develop instructional leadership with the PIMRS. In Shen, J., Tools for improving principals' work (pp. 47-69). New York: Peter Lang Publishing.

Hallinger, P. \& Murphy, J. (1985). Assessing the instructional management behaviour of principals. The elementary school journal, 86(2), 217-274.

Hussein Mahmod. (1998). Kepemimpinan dan keberkesanan sekolah. Kuala Lumpur: Dewan Bahasa Dan Pustaka.

Jemaah Nazir dan Jaminan Kualiti. (2017). Standard kualiti pendidikan malaysia gelombang 2 (SKPMg2). Putrajaya: Percetakan Pro Dinasti Sdn. Bhd.

Kemelimeda, Hairudinor, Ridwan, M. N., \& Dalle, J. (2018). The effect of motivation, job satisfaction, and job discipline toward employee performance of PT Buma Perindahindo at LNG Tangguh Site, Teluk Bintuni Regency, West Papua, Indonesia. European journal of human resource management studies, 2(1), 49-73.

Kementerian Pendidikan Malaysia (KPM). (2013). Pelan pembangunan pendidikan malaysia 20132015. Putrajaya: KPM.

M. Izham, M. H. \& Norziana, A. (2015). Peranan pengetua dalam pengurusan kokurikulum dari perspektif guru sekolah menengah kebangsaan zon keramat. Jurnal pendidikan malaysia, 40(2), 129-138.

M. Sani. I. (2013). Peranan guru kanan mata pelajaran dalam mempertingkatkan kualiti pengajaran guru-guru. Jurnal kurikulum \& pengajaran asia pasifik (1).

McClelland, J.L. (1978). Perception and masking of wholes and parts. Journal of experimental psychology: human perception and performance, 4, 210-223.

MacIntyre, P., MacKinnon, S. \& Clement, R. (2009). In D. Zoltan \& E. Ushioda (Eds.), Motivation, language identity and the L2 Self, (pp. 193-214). Bristol: Multilingual Matters.

Mehrabian, A. \& Bank, L. (1978). A questionnaire measure of individual differences in achieving tendency. Educational and psychological measurement, 38, 475-478. 
DOI: https://doi.org/10.47405/mjssh.v6i6.824

Muhammad Ruslan. (2020). Contribution of principal transformational leadership and interpersonal communication through work motivation on teacher performance at all state junior high schools in banjarmasin utara sub-district. Journal of k6, education, and management, 3(2), 178 - 186.

Nik Badrul Hisham Nik Ismail \& Mastura Mahfar. (2015). Hubungan antara gaya kepimpinan pengetua dengan motivasi dalam kalangan guru smk harian daerah kluang, johor. Sains humanika, 5(1), 9-18.

Nurul Syuhaida Mohamed, Nur Faeqah Binti Mohd Zakwan, Nur Anina Shuada Binti Abdul Rahman, Nurul Natasha Amira Bt Othaman \& Burhanuddin Bin Yazid. (2019). Kemahiran pengurusan dan pentadbiran dalam pendidikan. Johor: UTHO.

Ofojebe \& Ezugoh. (2010). Teachers' motivation and its influence on quality assurance in the Nigerian educational system. African Research Review (An International Multidisciplinary Journal Ethiopia), 4(2), 11-18.

Qamal Taqreem. (2018). Perbezaan antara pengurusan pendidikan dengan pentadbiran pendidikan. Diakses pada 15 Mac 2021 daripada https://www.scribd.com/document/425327934/PPP6024Eviden-Forum-1.

Santhanamary Anthony, Hamdan Said, Ismail Mohamad \& Mahani Mokhtar. (2015). Self-efficacy belief as a practical and parsimonious evaluation criterion in school leadership training. Mediterranean journal of social sciences, 6(1), 20-29.

Sinirah Ahmad \& Aida Hanim A. Hamid. (2021). Amalan kepimpinan distributif guru besar terhadap efikasi kendiri dalam kalangan guru prasekolah. Malaysian journal of social sciences and humanities (MJSSH), 6(1), 2504.

Siti Azira Jose \& Mohd Effendi @ Ewan Mohd Matore. (2021). Tinjauan literatur bersistematik: faktor burnout dalam kalangan guru. Malaysian journal of social sciences and humanities (MJSSH), 6(1), 168-186.

Sonja Sentočnik, Gregory C. Sales \& Jayson W. Richardson. (2016). Educational reform in georgia: recommendations for building leadership capacity as a critical success factor for instructional change. International journal of leadership in education, 21(6), 651-668. 